\title{
Nanocrystalline Thin Ceramic Films Synthesised by Pulsed Laser Deposition and Magnetron Sputtering on Metal Substrates for Medical Applications
}

\author{
Adele Carradò ${ }^{1}$, Hervé Pelletier ${ }^{2,3}$ and Thierry Roland ${ }^{3}$ \\ ${ }^{1}$ Institut de Physique et Chimie des \\ Matériaux de Strasbourg, UMR 7504 UDS-CNRS, \\ 2Institut Charles Sadron, CNRS UPR 22, Strasbourg \\ ${ }^{3}$ Institut National des Sciences Appliquées, Strasbourg
}

France

\section{Introduction}

A suitable design of an implant material is aimed to provide an essential functionality, durability and biological response. Functionality and durability depend on the bulk properties of the material, whereas biological response is governed by the surface chemistry, surface topography, surface roughness, surface charge, surface energy, and wettability (Oshida et al., 2010). The implants biocompatibility has been shown to depend on relationship with biomaterials, tissue, and host factors, being associated with both surface and bulk properties.

Research area of thin and nano-structured films for functional surfaces interests to enhance the surface properties of materials. Thin films are an important and integral part of advanced material, conferring new and improved functionalities to the devices. Also processing of thin coatings with reproducible properties is a major issue in life-time of implanted biomaterial.

Currently in the implantology, hydroxyapatite (HA), alumina $\left(\mathrm{Al}_{2} \mathrm{O}_{3}\right)$ and titanium nitride (TiN) have been widely chosen as thin biofilms to be coated on metal implants such as titanium materials and surgical 316L stainless steel.

HA coatings on titanium implants have been proposed as a solution for combining the mechanical properties of the metals with the bioactive character of the ceramics, leading to a better integration of the entire implant with the newly remodelled bone. HA has drawn worldwide attention as an important substitute material in orthopaedics and dentistry because of its chemical and biological nature similar to that of bone tissue ( $70 \%)$ (de Groot, 1983; Kohn \& Ducheyne, 1992; LeGeros \& LeGeros, 1993; Elliot, 1994), its biocompatibility, bioactivity and osteoconductivity (Hench, 1991).

$\mathrm{Al}_{2} \mathrm{O}_{3}$ for its excellent wear resistance (Husmann et al., 1998) high chemical inertness under physiological conditions and TiN for its chemical stability are also commonly used as biomaterials (Staia et al.,1995). This last one interlayer plays a role as a diffusion barrier and it exhibits excellent mechanical properties and chemical stability (Iliescu et al., 2004). 
Titanium materials (commercially pure titanium ASTM Grades 1 through 4 or Ti-based alloys) are considered to be the most biologically compatible materials to vital tissue (Oshida et al., 2010). Their more recent applications are in maxillofacial, oral and cardiovascular-surgery, as well as in orthopaedics indicating a superiority of titanium materials compared to stainless steel, Co-Cr-Mo alloys (Kasemo, 1983). However, they have no bioactivity as bone-substitute implant materials. These results in mechanical bonding rather than direct chemical bonding between the titanium implant material and the host bone tissue (Long \& Rack, 1998). According to various in-vitro and in-vivo tests, HA implant coatings have shown an improved bone apposition as compared to uncoated implants in the first several weeks after operation (Tisdel et al., 1994).

Surgical AISI 316L stainless steel is widely used in orthopaedic implantology, although biological complications may result from its insufficient mechanical and tribological properties (Bordji et al., 1996). 316L contains enough chromium to confer corrosion resistance by passivity. Nevertheless the passive layer is not enough stable and because of poor corrosion resistance of 316 L stainless steel under high stressed and oxygen-depleted regions, it is suitable to use it in temporary implant devices or coated with bioinert films.

Nowadays there are numerous thin film deposition techniques; most common are molecular beam epitaxy, plasma spray (PS), dipping, electro-codeposition, sol-gel-derived coating, magnetron sputtering (MS) and pulsed laser deposition (PLD) methods that have been developing rapidly during the last decades. Between them, MS and PLD are very powerful process, which are employed successfully in biomedical, functional and protective films. MS and PLD processes allow the control of the interface layer between the substrate material and the thin film, which in turn can be used to substantially improve the film adhesion to substrate. They are useful method for making thin films of functional biomaterials. A considerable amount of researches has been devoted to develop techniques for coating HA on titanium (Long \& Rack, 1998) such as plasma spraying (Yang, 1995; Weng et al.,1995), dipping (Li et al., 1996), electro-codeposition (Dasarathy et al., 1996), PLD (Cotell, 1994), sputtering (Yang et al., 2005) and sol-gel-derived coating (Carradò \& Viart, 2010).

Moreover, PLD (Pelletier et al., 2011) and MS (Carradò et al., 2010) can make thin TiN coatings, favourable for high fatigue resistance. In addition, TiN films should have good mechanical properties, i.e. a very strong adherence to the substrate, and hardness, Young modulus, stiffness and mechanical wear similar to those specific to human bone. Also a large variety of deposition techniques like PS (Liu et al. 2003), PLD (Carradò et al., 2008), MS (Trinh et al., 2008; Carradò et al., 2008), dipping and spinning (Babaluo et al., 2004) and solgel (G. Ruhi et al., 2008) have been approached for obtaining these oxides $\left(\mathrm{Al}_{2} \mathrm{O}_{3}\right)$.

We reported some example of bioinert alumina, titanium nitride and bioactive hydroxyapatite coated on titanium and stainless steel substrates and we investigated the micro-structural and mechanical characteristics of these bioceramic coatings on their substrates. Among the different methods to obtain ceramic coatings that we have chosen PLD and MS due to their versatility and controllability, the aptitude to synthesize and deposit uniform films, with an accurate control of the stoichiometry and crystallinity. Various microscopic observations and mechanical characterisations by nanoindentation and scratch tests were used in order to connect the mechanical response to the microstructure of the coatings. Our studies revealed that the pulsed-laser deposition and magnetron sputtering technique appear as extremely versatile technologies in biomedical applications. 


\section{Ceramic thin films for biomedical}

Many commercial replacement materials now have been developed as biomaterial for thin films, including metal, natural and synthetic polymers, corals and its derivatives and synthetic ceramics. These last ones can be divided roughly into three main types governed by the tissue response. In broad terms:

1. bioinert (alumina, titanium nitride, titanium dioxide, zirconia) materials have no or negligible tissue response;

2. bioresorbable (tricalcium phosphate (TCP), $\left.\mathrm{Ca}_{3}\left(\mathrm{PO}_{4}\right)_{2}\right)$ materials degradable and absorbed by the body;

3. bioactive materials (hydroxyapatite $\left.(\mathrm{HA}), \mathrm{Ca}_{10}\left(\mathrm{PO}_{4}\right)_{6}(\mathrm{OH})_{2}\right)$, bioactive glasses $(\mathrm{CaO}-$ $\mathrm{SiO}_{2}-\mathrm{P}_{2} \mathrm{O}_{5}-\mathrm{Na}_{2} \mathrm{O}$ ), and glass ceramics), encourage bonding to surrounding tissue with, for example, new bone growth being stimulated, or porous for tissue in growth (HA coating, and bioglass coating on metallic materials) (Hench, 1991; Cao \& Hench, 1996; Hench, 1998).

\subsection{Bioactive ceramic films}

Hydroxyapatite (HA) forms a real bond with the surrounding bone tissue when implanted. Even so, due to the poor mechanical properties of bulk HA ceramic, it cannot be used as implant devices to replace large bony defects or for load-bearing application as was described by Hench (Hench \& Wilson, 1993). Koch (Koch et al., 1990) presented HA has low mechanical strength, but very good osteointegration and biocompatibility. The use of HA coatings on titanium alloys leads to a structure that has good mechanical strength and good osteointegration properties at the surface (Lacefield, 1998). It has also been demonstrated that the bond between HA and bone is better than the bond between titanium and bone (Radin \& Ducheine, 1992; Filiaggi et al., 1993).

\subsection{Bioinert ceramic films}

Alumina $\left(\mathrm{Al}_{2} \mathrm{O}_{3}\right)$ is a highly inert material (Chiba et al., 2003) and resistant to most corrosive environments, including the highly dynamic environment that is the human body. Under physiological conditions, it is also extremely unreactive and is classed as nearly inert, eliciting little if any response from surrounding tissues and remaining essentially unchanged after many years of service. Due to its ability to be polished to a high surface finish and its excellent wear resistance, $\mathrm{Al}_{2} \mathrm{O}_{3}$ is often used for wear surfaces in joint and hip replacement prostheses (Hatton et al., 2002). Nevertheless, the body recognizes it as a foreign material and does attempt to isolate it by forming a layer of non adherent fibrous tissue around the implant where possible.

Titanium nitride (TiN) is known for its high surface hardness and mechanical strength. It was also reported that the dissolution of Ti ions is very low (Tamura et al., 2002). TiN coatings are often employ for improving the tribological performance in industrial applications due to its mechanical (Leng et al., 2001) and chemical properties including high hardness, low wear coefficient (Holmberg \& Matthews, 1994). It is biologically inert and tolerated by living tissues (Kao et al., 2002). Moreover, the TiN interlayer produces improvement of HA film mechanical performances, by increasing its bond strength and adherence (Nelea et al., 2002; Ducheyne et al., 1993). 


\section{Deposition techniques}

\subsection{Magnetron sputtering (MS)}

Magnetron sputtering (MS) is a very powerful technique which is used in a wide range of applications due to its excellent control over thickness and uniformity, excellent adherence of the films and its versatility in automatization (Wasa et al. 2003).

A strong potential difference is applied in a gas, generally of argon, with possibly reactive gases $\left(\mathrm{O}_{2}, \mathrm{~N}_{2}\right.$, etc.). It causes the ionization of the gas atoms and the creation of plasma. These ions are accelerated by the potential difference and strike the target surface. Target atoms are then ejected by mechanical action and condense on the substrate. Target electrons are also ejected and enter in collision with gas atoms, which causes their ionization and allows the maintenance of plasma (Fig. 1). Two types of power supply can be used: alternate radio frequency $(\mathrm{RF})$ or direct current $(\mathrm{DC})$. RF is used to deposit insulators, indeed in DC one uses a stronger tension to compensate for the resistivity of the target.
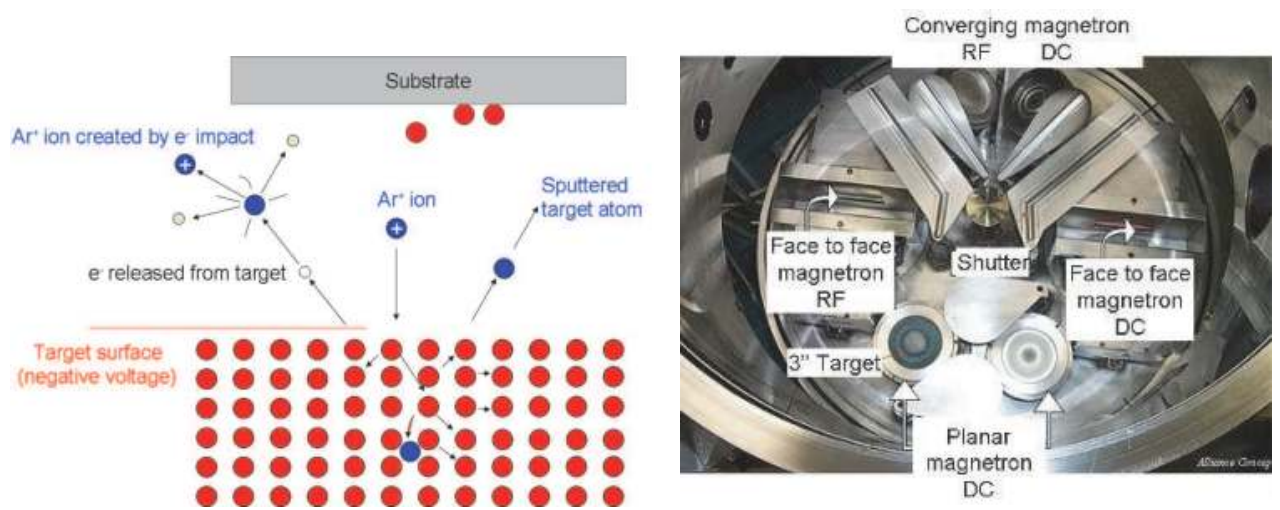

Fig. 1. Schematic principle of magnetron sputtering (MS) and picture of MS apparatus

\subsection{Pulsed Laser Deposition (PLD)}

Pulsed laser deposition (PLD) is for many reasons a versatile technique. Since with this method the energy source is located outside the chamber, the use of ultrahigh vacuum as well as ambient gas is possible (Krebs et al., 2003) (Fig. 2). Combined with a stoichiometry transfer between target and substrate this allows depositing all kinds of different materials (e.g. oxides, nitrides, carbides, semiconductors, metals and even polymers) can be grown with high deposition rates. The preparation in inert gas atmosphere makes it even possible to tune the properties (stress, texture, reactivity, magnetic properties...) by varying the kinetic energy of the deposited particles. All this makes PLD an alternative deposition technique for the growth of high-quality thin films (Fernandez-Pradas et al., 1998; Jelínek et al., 1995; Mayor et al., 1998; Fernández-Pradas et al., 2002; Arias et al., 1997).

Because of its capability to restore complex stoichiometry and to produce crystalline and adherent films, PLD stands for a challenge to plasma spraying that for the moment is the only commercially available technique for HA coatings deposition used in bone implantology (Zeng \& Lacefield, 2000; Chen et al., 1997; Feng et al., 2000). However, it is generally accepted nowadays that plasma spraying produces porous films with poor crystallinity, exhibiting a low adherence to the metallic substrate (Carradó, 2010). PLD is an 
alternative method to coat metal substrates with HA in order to improve both the chemical homogeneity and the mechanical properties of calcium phosphate coatings (Nelea et al., 2006). PLD has successfully produced HA coatings with various compositions and crystallinity (Arias et al., 2002). Moreover, PLD can synthesize thin HA coatings, adequate for high fatigue resistance.
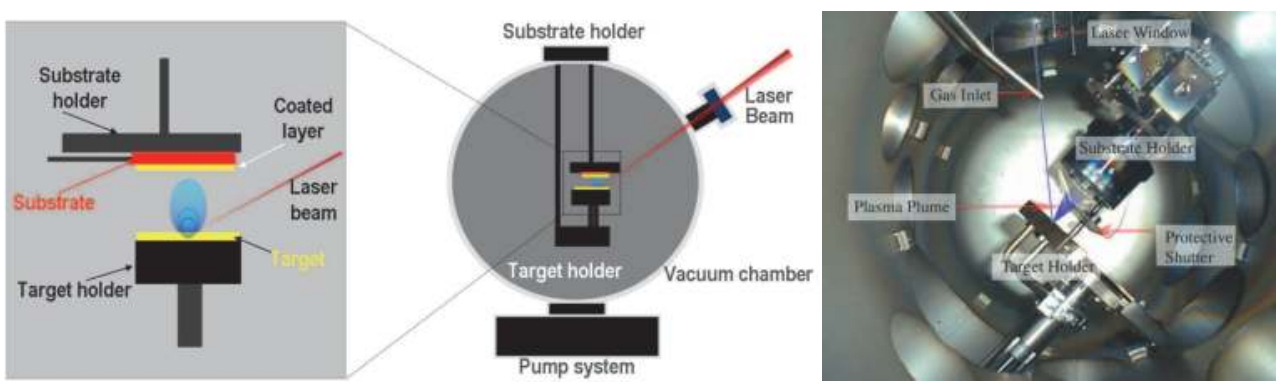

Fig. 2. Schematic principle of Pulsed laser deposition (PLD)

\section{Experimental details}

\subsection{Bioinert $\mathrm{Al}_{2} \mathrm{O}_{3}$ interlayer}

$\mathrm{Al}_{2} \mathrm{O}_{3}$ was deposed on stainless steel (grade $304 \mathrm{~L}$, Table 1) substrate- square pieces $\left(1 \times 1 \times 10 \mathrm{~mm}^{3}\right) . \mathrm{Al}_{2} \mathrm{O}_{3}$ was applied as an inert interlayer to improve the adhesion of bioceramic films to the metallic substrate. The surgical stainless steel substrate was mechanically polished and then cleaned with methylene chloride and methanol. A dynamical pressure of $\mathrm{O}_{2}$ was stabilized inside the PLD chamber and maintained during the whole deposition cycle. During the deposition, the stainless steel substrate was kept at $200{ }^{\circ} \mathrm{C}$.

Prior deposition the substrates of stainless steel were mirror-polished and then cleaned ultrasonically in $\mathrm{CH}_{2} \mathrm{Cl}_{2}$ and $\mathrm{CH}_{3} \mathrm{OH}$. The studied alumina coatings were deposited onto these substrates by PLD and MS.

\begin{tabular}{|c|c|c|c|c|c|c|c|c|}
\hline & \multicolumn{8}{|c|}{$\begin{array}{c}\text { Alloy composition } \\
{[\mathrm{wt} \%]}\end{array}$} \\
\hline & $C_{\max }$ & Si max & Mn max & $S \max$ & $\mathrm{Cr}$ & $\mathrm{Ni}$ & $\mathrm{N}$ & $\mathrm{Cu}$ \\
\hline $316 \mathrm{~L}$ & 0.03 & 1.0 & 2.0 & 0.03 & $17.5 / 19.5$ & $8.0 / 10.0$ & 0.045 & $\leq 0.11$ \\
\hline
\end{tabular}

Table 1. Chemical composition in wt of surgical 304L stainless steel

Magnetron sputtered samples were prepared at low substrate temperature $\left(200{ }^{\circ} \mathrm{C}\right)$ by reactive $\left(\mathrm{O}_{2}\right)$ direct current sputtering on a planar magnetron. The deposition parameters are summarized in Table 2. Before deposition, the surface of the substrates was cleaned by a 30 minutes plasma etching.

PLD coatings were produced using an excimer laser $\mathrm{KrF}^{*}$ emitting at $\lambda=248 \mathrm{~nm}$, by $20 \mathrm{~ns}$ pulses at $10 \mathrm{~Hz}$ and a sintered alumina target. As for MS samples, the substrates were maintained at $200{ }^{\circ} \mathrm{C}$ during the deposition time. Prior to the deposition, the pressure in the chamber was $5 \times 10^{-6} \mathrm{~Pa}$. Table 3 sums up the deposition parameters. 


\begin{tabular}{|c|c|}
\hline Sample & MS \\
\hline Target & $\mathrm{Al}$ \\
\hline Substrate temperature $\left[{ }^{\circ} \mathrm{C}\right]$ & 200 \\
\hline Dynamical pressure $[\mathrm{Pa}]$ & 600 \\
\hline $\mathrm{IDC}[\mathrm{mA}]$ & 180 \\
\hline $\mathrm{P}[\mathrm{W}]$ & 17.5 \\
\hline Deposition time $[\mathrm{h}]$ & 1.0 \\
\hline Coating thickness $[\mu \mathrm{m}]$ & $\mathrm{Ar} 15 \mathrm{sccm}$ and $\mathrm{O}_{2} 8 \mathrm{sccm}$ \\
\hline
\end{tabular}

Table 2. Experimental conditions for $\mathrm{MS}_{\mathrm{Al}_{2} \mathrm{O}_{3} \text { coatings }}$

\begin{tabular}{|c|c|c|c|}
\hline Samples & PLD 4 & PLD 5 & PLD 6 \\
\hline Fluency [J/cm $\left.{ }^{2}\right]$ & 1.5 & & \\
\hline Dynamical pressure [Pa] & $6 \times 10^{-5}$ & 5 Pa with $\mathrm{O}_{2} 10 \mathrm{sccm}$ & 1 Pa with $\mathrm{O}_{2} 10 \mathrm{sccm}$ \\
\hline Deposition time (hours) & & 4.5 & 1.2 \\
\hline Coating thickness $(\mu \mathrm{m})$ & 1.2 & 0.6 & \\
\hline Pulse duration $(\mathrm{ns})$ & & 20 & 180,000 \\
\hline Pulse repetition rate $(\mathrm{Hz})$ & & 10 & \\
\hline Number of pulses & 150,000 & 150,000 & 0.04 \\
\hline Substrate temperature $\left({ }^{\circ} \mathrm{C}\right)$ & & 200 & \\
\hline $\operatorname{Ra}(\mu \mathrm{m})$ & 0.01 & 0.03 & \\
\hline
\end{tabular}

Table 3. Experimental conditions for Pulsed Laser Deposition $\mathrm{Al}_{2} \mathrm{O}_{3}$ coatings

The coatings surface morphology was investigated using a field emission microscope JEOL JSM-6700F. The chemical analysis of the thin films was investigated using an energy dispersive X-ray analyzer (Oxford Instruments). The crystal structure of the films was studied with a Selected Area Electron Diffraction (SAED) of Transmission Electron Microscopy (TEM) with a Topcom EM 002B microscope equipped with a small dose sensitive camera and $\mathrm{a} \mathrm{Si} / \mathrm{Li}$ detector.

\subsection{Bioactive hydroxyapatite coatings: experimental details}

An $\mathrm{UV} \mathrm{KrF}^{*}$ laser source $(\lambda=248 \mathrm{~nm}, \tau=10 \mathrm{~ns})$, placed outside the irradiation chamber, was used. The laser radiation was focused with a an anti-reflection coated $\mathrm{MgF}_{2}$ cylindrical lens with a focal length of $30 \mathrm{~cm}$ and was incident at $45^{\circ}$ onto the target surface. The targets were mounted in a special holder which was rotated and/or translated during the application of the multi-pulse laser irradiation in order to avoid piercing and to continuously submit a fresh zone to laser exposure. A multi structure of the type HA/Ti/ was grown on a titanium substrate. A multi-target carousel was used to facilitate the target exchange, in order to avoid exposition of growing films to open air. Commercial titanium (Ti grade 4), and $99.98 \%$ pure HA targets have been subsequently used.

Two Ti Grade 4 substrates $(\varnothing=15 \mathrm{~mm}$, thickness $=2 \mathrm{~mm})$ were prepared with a final polishing by silicon carbide sandpaper (1200\#) and finally treated chemically. The chemical etching consisted in a pre-treatment by specimen immersion in $1 \mathrm{M}$ sodium hydroxide and $0.5 \mathrm{M}$ hydrogen peroxide at $75{ }^{\circ} \mathrm{C}$ for 10 minutes for cleaning and decontaminating the titanium surface from embedded particles and machining impurities. After 10 minutes of treatment in $0.2 \mathrm{M}$ oxalic acid at $85^{\circ} \mathrm{C}$ to produce a microporous surface and a final immersion in nitric acid for final passivation was done. The Ti interlayer was interposed 
between the initial titanium substrate and the HA film, to minimize interface stresses. Finally, one sample was kept as it was (HA-2, Table 4) and the second was treated for 6 hours in an atmosphere enriched in water vapours (HA-1, see Table 4) in order to improve the HA crystallinity status and to restore the loss of $\mathrm{OH}$ groups from the HA molecule. The deposition conditions are collected in Table 4.

\begin{tabular}{|l|c|c|c|c|c|}
\hline & Target & Temperature $\left[{ }^{\circ} \mathrm{C}\right]$ & Pression [Torr] & Pulses & Water vapours treatment \\
\hline HA- 1 & Ti & RT & $10^{-6}$ & 40000 & \\
\hline & $\mathrm{HA}$ & 400 & $10^{-6}$ & 500 & \\
\hline & $\mathrm{HA}$ & 400 & $0.35 \mathrm{H}_{2} \mathrm{O}$ & 30000 & \\
\hline HA-2 & $\mathrm{Ti}$ & $\mathrm{RT}$ & $10^{-6}$ & 40000 & \\
\hline & $\mathrm{HA}$ & 400 & $10^{-6}$ & 500 & \\
\hline & $\mathrm{HA}$ & 400 & $0.35 \mathrm{H}_{2} \mathrm{O}$ & 30000 & without treatment \\
\hline
\end{tabular}

Table 4. Experimental conditions of HA films with and without water vapours

\section{Structural and microstructural characterisation}

Preliminary X-ray diffraction was performed for detecting the crystalline phases of the coatings. Only the characteristic peak pattern of austenitic Fe corresponding of 33-0397 JCPDS was displayed. Consequently the alumina coatings seem to be amorphous. Nonetheless, in case of $\mathrm{MS} \mathrm{Al}_{2} \mathrm{O}_{3}$ films grown at $200{ }^{\circ} \mathrm{C}$, selected area electron diffraction (SAED) reveals a fine crystallization in the $\mathrm{\gamma}-\mathrm{Al}_{2} \mathrm{O}_{3}$ phase (Fig. 3b). The SAED pattern corresponds to the tetragonal $\gamma-\mathrm{Al}_{2} \mathrm{O}_{3}$ polycrystalline structure, with reticular parameters $\mathrm{a}=$ $\mathrm{b}=0.57 \mathrm{~nm}$ and $\mathrm{c}=0.79 \mathrm{~nm}$. The MS film deposited shows the characteristic 311, 400, 511, 440 and 444 rings of polycrystalline aluminium oxide and the continuity of the rings in the first selected area diffraction indicates the presence of randomly oriented grains of very fine dimension (Fig. 3a). Whereas, as clearly shown in PLD $\mathrm{Al}_{2} \mathrm{O}_{3}$ films at $200{ }^{\circ} \mathrm{C}$ (Fig. 3c) samples is generally amorphous with a reduced number of small grain (Carradò et al., 2008). Laser deposited coatings have a smooth surface (Fig. 4a), with alumina particulates deposited on the film or embedded into the film. These particulates generally are either spherical, with a diameter between several hundreds of nanometers and one micrometer, or discoidal, with a diameter usually exceeding one micrometer (Fig. 4b,c). MS samples exhibit a smooth surface which follows closely the topography of the substrate. Spherical alumina particulates with approximately $100 \mathrm{~nm}$ diameter lay on top of the alumina film. They are generally agglomerated in structures resembling coral (Fig. 4d).

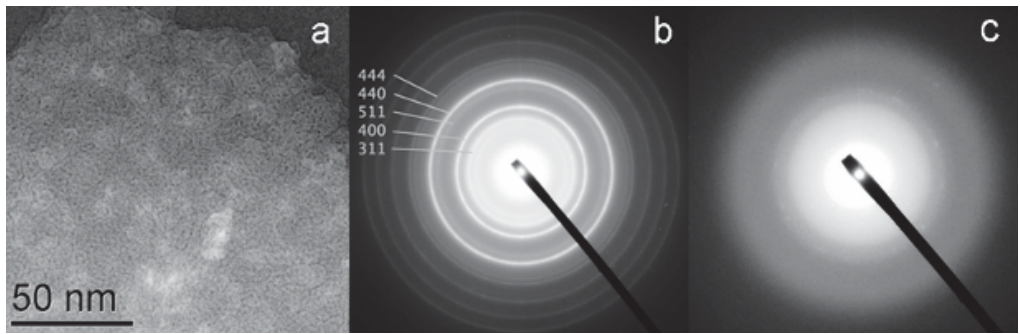

Fig. 3. High-resolution TEM (HRTEM) plan-view image or Bright field of MS film (a) and SAED patterns of MS2 (b) and of PLD5 (c) 
These structures are spread on areas up to $60 \mu \mathrm{m}$ diameter. EDS measurements demonstrate that the coatings have a chemical composition close to stoichiometric $\mathrm{Al}_{2} \mathrm{O}_{3}$ ( $\mathrm{Al}: 34 \%, \mathrm{O}$ : $66 \%$, for MS coatings, and $\mathrm{Al}: 38 \%$, O: $62 \%$, for PLD coatings).

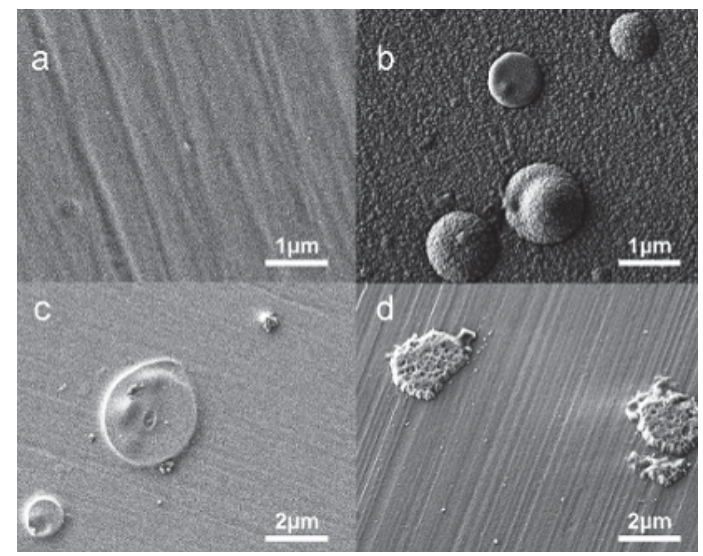

Fig. 4. (a-c) Typical SEM micrographs of an $\mathrm{Al}_{2} \mathrm{O}_{3}$ film consisting evidencing a smooth film with embedded droplets. (a) PLD4 sample, without $\mathrm{O}_{2}$; (b) PLD 5 working pressure of $5 \mathrm{~Pa}$, with $\mathrm{O}_{2} 10 \mathrm{sccm}$. The scale bar is $1 \mu \mathrm{m}$ (c) PLD 6 coatings deposed with working pressure of $1 \mathrm{~Pa}$, with $\mathrm{O}_{2} 10 \mathrm{sccm}$. (d) MS coatings deposed with working pressure of 0.4 with Ar 15 $\mathrm{sccm}$ and $\mathrm{O}_{2} 8 \mathrm{sccm}$

In Fig. 5 some typical SEM micrographs of the PLD HA film are given. The surface is compact and well-crystallized and exhibits an irregular morphology principally due to the chemical etching of the substrate. Some grain-like particles and droplets were observed on the surface of the film, characteristic to PLD coatings (Cottel, 1994). The morphology of the droplets suggests that they might be a result of target splashing in liquid phase (Fig. 5b, insert), since the droplet diameter is much smaller than the particle size of the powder used to prepare the HA target. SAED-TEM image (insert in Fig. 6) reveals a polycrystalline structure of the ceramic film, consisting of nanometric crystalline HA domains. The desired formation of a graded layer of about $20-25 \mathrm{~nm}$ thickness can be clearly observed. Atomic plane of grains are visible in some regions, demonstrating the polycrystalline structure of the HA layer.

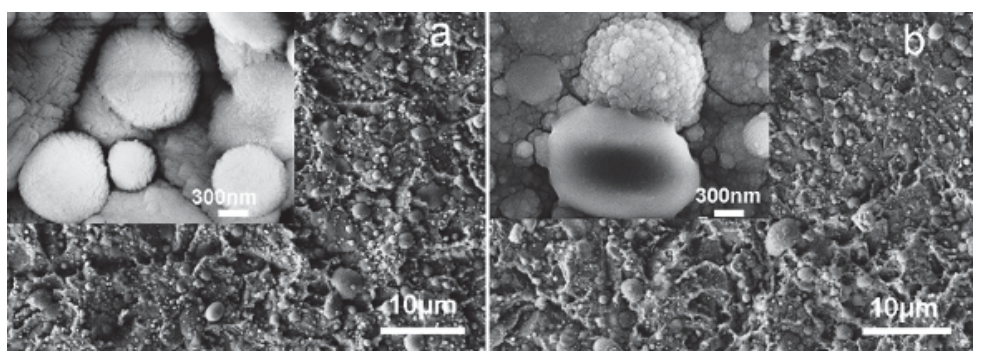

Fig. 5. (a) SEM micrograph of a HA film (HA-2, without water treatment). Particles of various sizes are visible with the larger ones been porous in (a) and smooth and vitreous in (b, HA-1, with water treatment) 


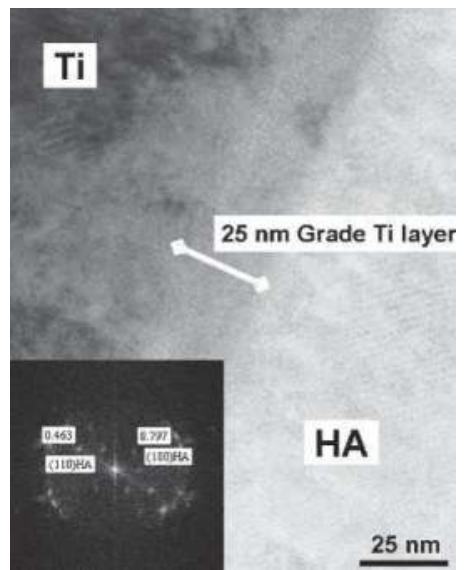

Fig. 6. HRTEM image of the HA/Ti interface. The presence of the graded layer is evidenced

\section{Mechanical and tribological characterization}

As described before, bioceramics such as $\mathrm{Al}_{2} \mathrm{O}_{3}$ and $\mathrm{HA}$ are currently used as biomaterials for many biomedical applications partly because of their ability to form a real bond with the surrounding tissue when implanted (Cao et al, 1996). However, usually the main weakness of this material lies in their poor mechanical strength that makes them unsuitable for loads bearing applications.

Our study is focused on understanding the mechanical characteristics and the tribological behaviour of a bioinert $\mathrm{Al}_{2} \mathrm{O}_{3}$ and a bioactive $\mathrm{HA}$ according to their micro-structural features processed by MS or PLD under several deposition conditions. The micro hardness, $H$, and elastic modulus, $E$, of the layers were measured using a nanoindentation system and a nano scratch experiments were employed to understand their wear mechanisms.

The literature devoted to mechanical properties of bioceramics is not sufficiently exhaustive and this section intends to give some clarifications.

\subsection{Nanoindentation}

The mechanical properties of the $\mathrm{Al}_{2} \mathrm{O}_{3}$ and HA bioceramics coated by MS or PLD were analysed by nanoindentation technique using a Nanoindenter XP developed by MTS Systems Corporation. In this technique, a diamond tip (Berkovich indenter) was drawn into the surface under very fine depth and load control. The reaction force $(\mathrm{P})$ was measured as a function of the penetration depth $(\mathrm{h})$, both during penetration (loading phase) and during removal (unloading phase), with high load and displacement resolutions (50 $\mathrm{nN}$ and $0.04 \mathrm{~nm}$ respectively). $H$ and $E$ were deduced from the recorded load-displacement curve using the Oliver and Pharr procedure (Oliver et al. 1992). The force required to indent for a particular applied load (and its corresponding penetration depth) gives a measure of the hardness of the material, while the response of the material during removal indicates the apparent elastic modulus. Due to the low thicknesses of the coatings (500 to $1200 \mathrm{~nm}$ ), the indentation tests were performed at shallow indentation depth to avoid or limit the effect of the substrate. Moreover, to follow the evolution of $H$ and $E$ values (in accordance to the indentation depth during loading phase) several partial unloading phases were introduced in order to estimate 
the different contact stiffnesses. Consequently, the substrate effect on nanoindentation measurements was deduced. Prior to test, the Berkovich triangular pyramid was calibrated using the fused-silica samples following the Oliver and Pharr procedure (Oliver et al., 1992). Fig. 7 illustrates the experimental load-displacement curves obtained from the different bilayer $\mathrm{Al}_{2} \mathrm{O}_{3} / 304 \mathrm{~L}$ systems (samples MS and PLD 5) whereas Fig. 8 shows the evolution of $H$ and $E$, estimated on the $304 \mathrm{~L}$ substrate as a function of the applied load $(\mathrm{P})$ and the corresponding penetration depth (h).
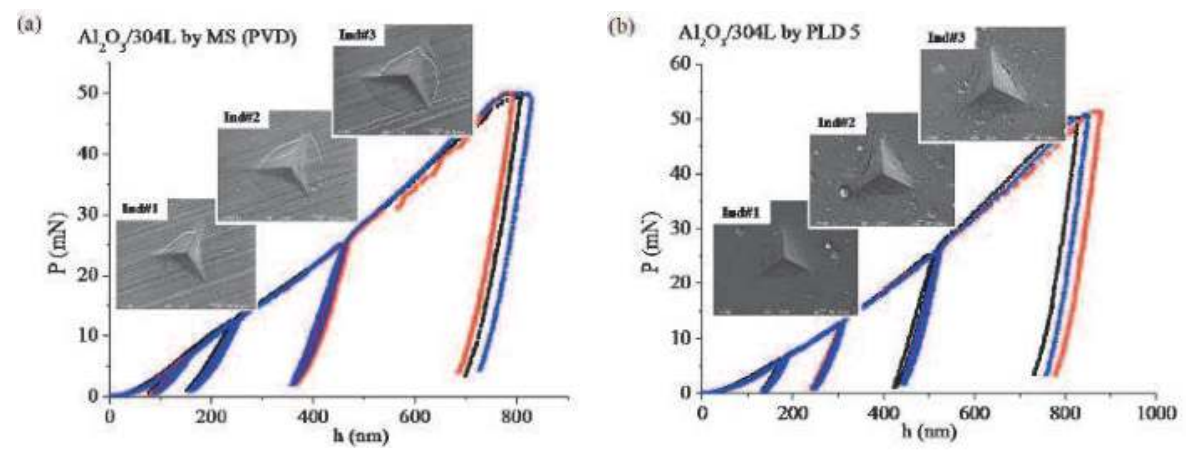

Fig. 7. Load-displacement curves obtained on $\mathrm{Al}_{2} \mathrm{O}_{3} / 304 \mathrm{~L}$ systems processed by (a) MS and (b) PLD 5

To obtain the $H$ of a coated film, the indentation depth should be about ten times smaller than the film thickness, in case of a harder film deposited on a soft substrate (Buckle, 1973). Nevertheless, it mainly depends on (i) the mechanical properties of the film and of the substrate (ratios $\mathrm{H}_{\mathrm{f}} / \mathrm{H}_{\mathrm{s}}$ and $\mathrm{E}_{\mathrm{f}} / \mathrm{E}_{\mathrm{s}}$ ), (ii) the indenter shape and (iii) the interface adhesion (Sun, 1995). Basically, the substrate effect on the determination of the $\mathrm{H}_{\mathrm{f}}$ and $\mathrm{E}_{\mathrm{f}}$ by nanoindentation is directly related to the expansion of the elastically and plastically deformed volume underneath the indenter during the loading phase. This critical depth normalized by the film thickness $\left(h_{c} / t\right)$ may vary between 0.05 and 0.2 . The evolution of the composite hardness with indentation depth was predicted by various methods and models.
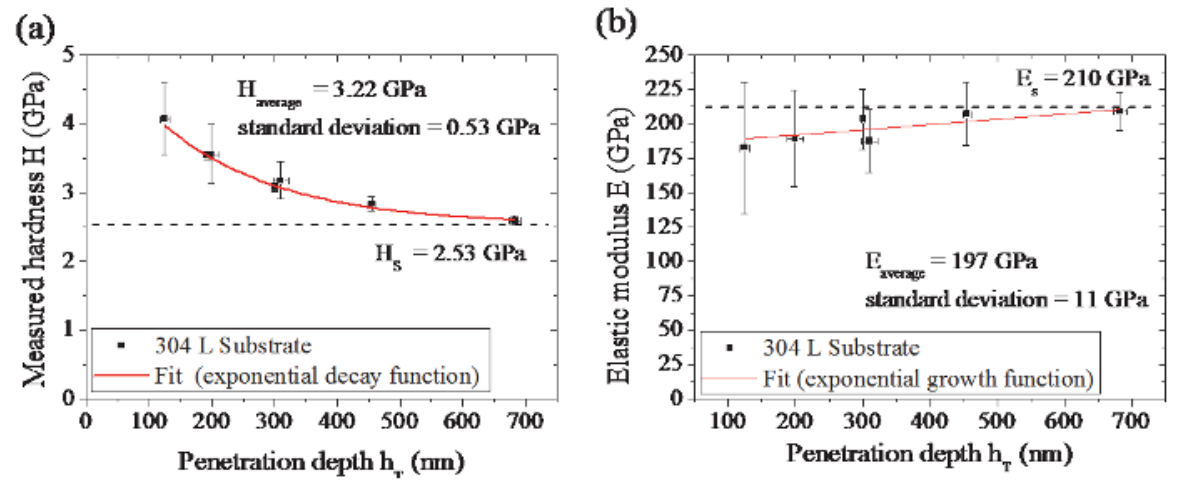

Fig. 8. (a) Hardness and (b) elastic modulus as function of penetration depth determined from the $304 \mathrm{~L}$ substrate without coating 
In our study, due to the deposition of a hard film on a softer substrate, the analytical expression of Eq. 1 (Korsunsky, 1998) was used to extract the true $\mathrm{H}_{\mathrm{f}}$ and $\mathrm{E}_{\mathrm{f}}$ for the MS and $\mathrm{PLD} \mathrm{Al}_{2} \mathrm{O}_{3}$ films:

$$
H_{\text {mes }}=H_{s}+\frac{H_{f}-H_{s}}{1+k\left(\frac{h_{c}}{t}\right)^{2}}
$$

where $\mathrm{k}$ is a fitting parameter. Here again, the contact depth is determined according to the Oliver and Pharr procedure (Oliver, 1992).

Fig. 9 shows the evolutions of the composite hardness as a function of the indentation contact depth normalized to the coating thicknesses of the samples PLD 4, PLD 5 and PLD 6 and it can be seen that the previous equation can successfully described the shape of these curves.

(a)

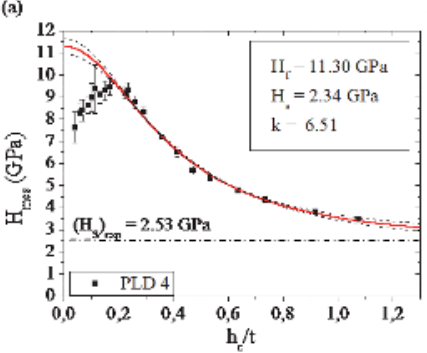

(b)

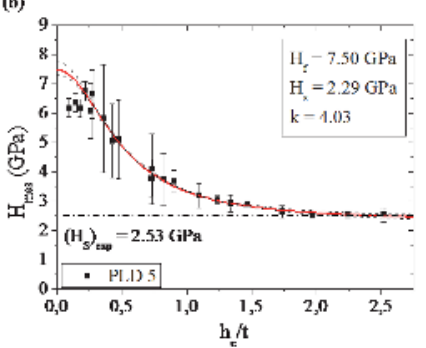

(c)

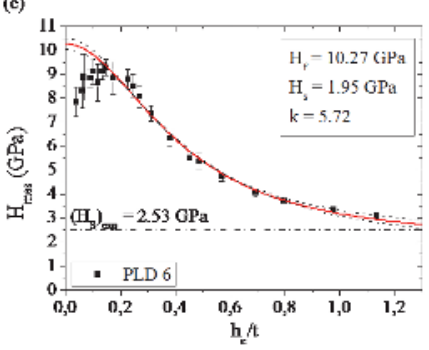

Fig. 9. Evolution of the harness according to the ratio $\left(h_{c} / t\right)$ for the sample (a) PLD 4 , (b) PLD 5 and (c) PLD 6

Using the same fitting equation (Eq. 1) the hardness of the MS sample was measured. Figure 10 shows MS sample hardness measured values compared to PLD 4. The values of $\mathrm{H}_{\mathrm{f}}, \mathrm{H}_{\mathrm{s}}$ and $E_{\mathrm{f}}$ are reported in Table 5. To determine the elastic modulus $\mathrm{E}_{\mathrm{f}}$ of a film deposited on a substrate, a model should also be used to account for the substrate effect (Saha and Nix, 2002). But, in a first approach, the average of elastic modulus is obtained by the plateau region of the curves (see Fig. 10 and Fig. 11). From these curves, an average value of $E_{\mathrm{f}}$ was obtained and reported in Table 5, assuming a Poisson coefficient of $v=0.3$ and $v=0.25$ for the 304L substrate and for the coatings respectively.
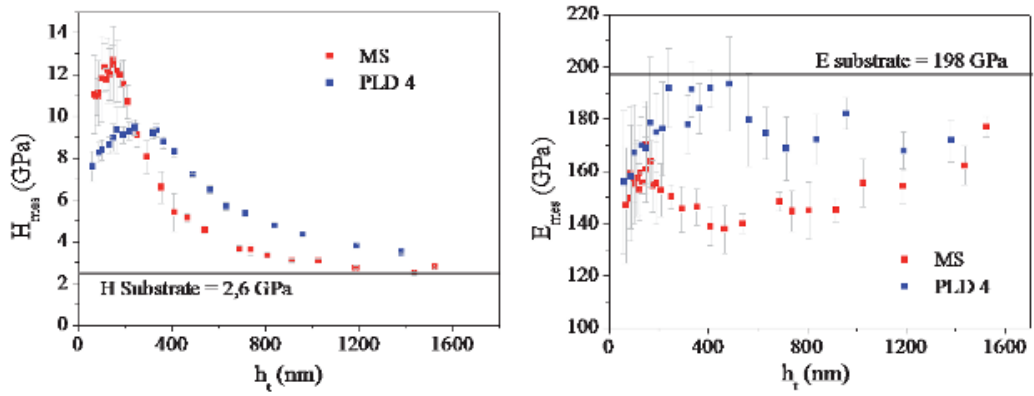

Fig. 10. Hardness and elastic modulus evolutions as function of the penetration depth $\left(h_{t}\right)$ of MS and PLD 4 samples 


\begin{tabular}{|c|c|c|c|}
\hline Sample & $\mathrm{H}_{\mathrm{f}}[\mathrm{GPa}]$ & $\mathrm{H}_{\mathrm{s}}[\mathrm{GPa}]$ & $\mathrm{E}_{\mathrm{f}}[\mathrm{GPa}]$ \\
\hline MS & $12.10 \pm 1.23$ & $2.60 \pm 0.30$ & $158 \pm 13$ \\
\hline PLD 4 & $11.29 \pm 0.35$ & $2.34 \pm 0.30$ & $180 \pm 15$ \\
\hline PLD 5 & $7.50 \pm 0.25$ & $2.29 \pm 0.10$ & $150 \pm 20$ \\
\hline PLD 6 & $10.27 \pm 0.25$ & $1.95 \pm 0.30$ & $178 \pm 13$ \\
\hline
\end{tabular}

Table 5. Mechanical properties of $\mathrm{Al}_{2} \mathrm{O}_{3}$ films determined by nanoindentation (using Eq. 1)

Fig. 9 illustrates a small difference between the experimental data and the fitting curves that could be explained by fracture phenomenon around the tip, defined by the physical meaning of the $\mathrm{k}$ parameter. In fact, SEM observations of the residual imprints (Fig. 12) show the formation of cracks in the contact zone for MS and PLD 5 layers. These cracks are related to the local microstructure and are predominately present on sample processed by MS and PLD5. They indicated the fragility of $\mathrm{Al}_{2} \mathrm{O}_{3}$ films compared to other ones which seem more ductile. Furthermore, it could also be linked to the smaller thickness of the $\mathrm{Al}_{2} \mathrm{O}_{3}$ coating in case of PLD $5(0.5 \mu \mathrm{m})$ compared to PLD 4 and PLD $6(1.2 \mu \mathrm{m})$.

It appears clearly that nanoindentation was relevant to extract the mechanical properties of the bioceramics films combined with microstructural observations showing the fragility aspects of the MS and PLD 5 films. For all samples, $\mathrm{H}_{\mathrm{f}}$ and $\mathrm{E}_{\mathrm{f}}$ values were in good agreements with those found by $\mathrm{Ahn}$ (Ahn, 2000) or Knapp (Knapp, 1996) for $\mathrm{Al}_{2} \mathrm{O}_{3}$ deposited by Radio Frequency sputtering or pulsed laser deposition respectively.
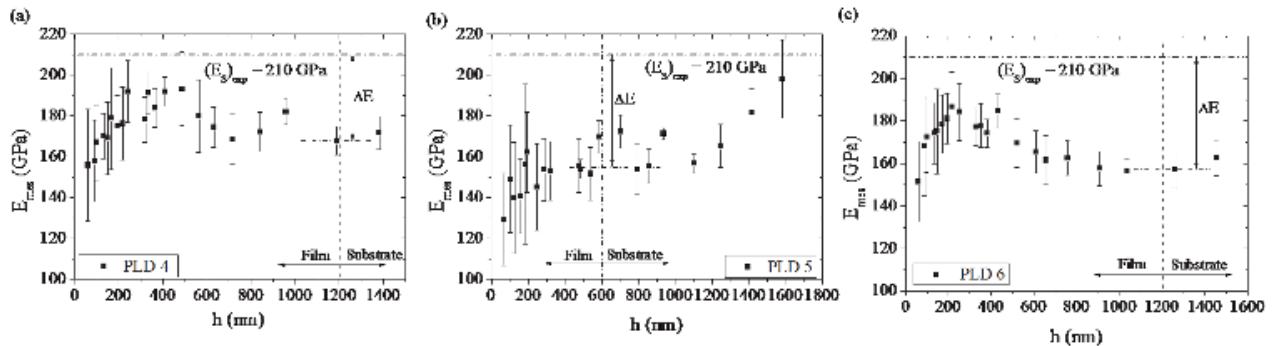

Fig. 11. Evolution of the elastic modulus for composite systems PLD 4, PLD 5 and PLD6
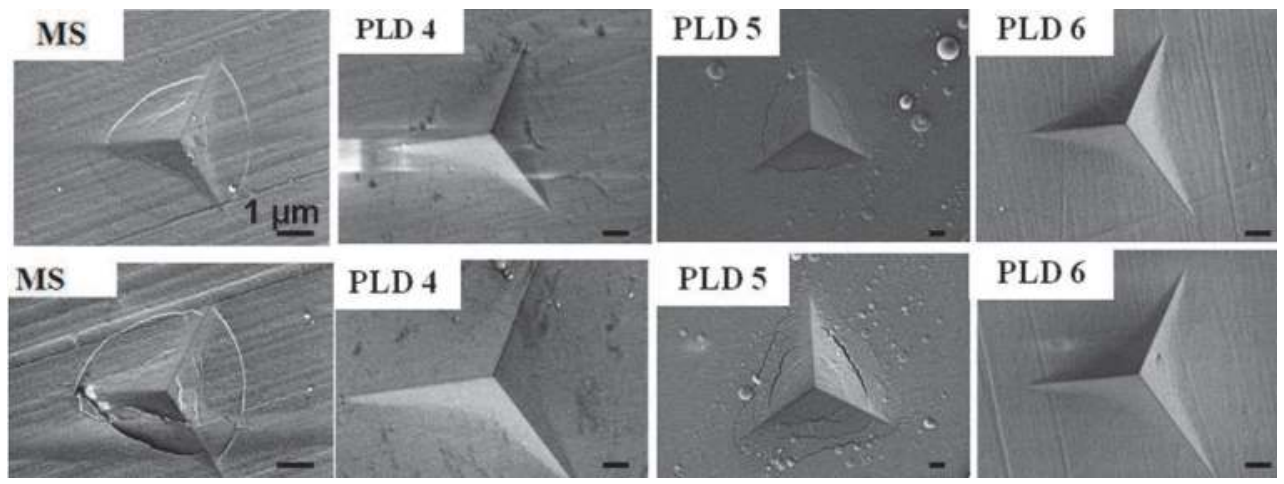

Fig. 12. SEM observations of the residual imprints for indentation test performed at $\mathrm{h}_{\mathrm{T}}=0.5 \mu \mathrm{m}$ (first line of images) and $\mathrm{h}_{\mathrm{T}}=1 \mu \mathrm{m}$ (second range of images) 
Nanoindentation experiments on bioactive hydroxyapatite layer (HA-1 and HA-2) PLD coated on massive Ti substrate were carried out and treated as described in this section. Due to the high porous and heterogeneous HA morphology (Fig. 5) a high scattering data was shown. Indeed, at low load, the scattering is related to the surface roughness and the surface morphology. Using a linear approximation, it was further possible to estimate the $H$ and $E$ values at the penetration depth of $100 \mathrm{~nm}$ that corresponds to several percent of the film thickness and thus to the intrinsic values of the mechanical properties of the tested HA coatings. Table 6 summarizes the obtained results.

\begin{tabular}{|c|c|c|}
\hline Sample & H [GPa] & E [GPa] \\
\hline HA-1 & $2.5 \pm 0.5$ & $80 \pm 20$ \\
\hline HA-2 & $1.7 \pm 0.5$ & $65 \pm 20$ \\
\hline
\end{tabular}

Table 6. Experimental values of $\mathrm{H}$ and $\mathrm{E}$ for $\mathrm{HA}$ coatings determined by nanoindentation

The values of nanohardness and elastic modulus experimentally determined in this study are in good agreements with the literature (Nieh, 2001; Deg, 2009). Most of them reported values of $\mathrm{E}$ and $\mathrm{H}$ determined by nanoindentation technique with a Berkovich indenter for plasma sprayed HA coatings on Ti ranging from 83 to $123 \mathrm{GPa}$ and 4 to $5 \mathrm{GPa}$, respectively (Zhang, 2001).

\subsection{Nanoscratch}

In recent years, scratch testing has become a more popular and meaningful way to address coating damage and seems able to overcome the deficiencies found in other more subjective test methods. It involves the translation of an indenter of a specified geometry subjected to a constant or progressive normal load across a surface for a finite length at either constant or increasing speed. At a certain critical load the coating may start to fail. The beginning of the scratch can be taken as truly representative of the resistance of the investigated materials towards penetration of the indenter before scratching. The critical loads can be confirmed and correlated with observations from optical microscope. Fig. 13 schematically describes the scratch tester.

The scratch testers measure the applied normal force, the tangential (friction) force and the penetration and the residual depth $(\mathrm{Rd})$. These parameters provide the mechanical signature of the coating system. Using this general protocol, it becomes possible to effectively replicate the damage mechanisms and observe the complex mechanical effects that occur due to scratches on the surface of the coating.

A typical scratch experiment is performed in three stages: an original profile, a scratch segment and a residual profile (Fig. 13). The actual penetration depth $\left(\mathrm{h}_{\mathrm{T}}\right)$ of the indenter and the sample surface are estimated by comparing the indenter displacement normal to the surface during scratching with the altitude of the original surface, at each position along the scratch length.

The original surface morphology is obtained by profiling the surface under a very small load at a location where the scratch is to be performed. Figure 13 defines the different steps of a classical scratch procedure. Roughness and slope of the surface are taken into account in the calculation of the indenter penetration.

The parameter commonly used to define the scratch resistance of the material, when fracture is involved, is the critical load. This parameter is the load at which the material first 
fractures. LC1 and LC2 are the critical load values which correspond, respectively, to failure and detachment of the coating. The fracture events can be visible on both the microscope view and the penetration curves.

All scratch experiments were performed with a spherical indenter with a tip radius $R=5 \mu \mathrm{m}$ and at a constant sliding velocity of $\mathrm{V}_{\text {tip }}=10 \mu \mathrm{m} \mathrm{s}^{-1}$. The parameters used for these experiments are reported in Table 7.

\begin{tabular}{|c|c|c|c|c|}
\hline Scratch & Starting load $[\mathrm{mN}]$ & Maximum load $[\mathrm{mN}]$ & Loading rate $[\mathrm{mN} / \mathrm{s}]$ & Scratch length $\mathrm{L}_{\mathrm{R}}[\mu \mathrm{m}]$ \\
\hline$\# 1$ & 1 & 16 & 0.3 & 500 \\
\hline$\# 2$ & 10 & 25 & 0.3 & 500 \\
\hline$\# 3$ & 20 & 40 & 0.4 & 500 \\
\hline$\# 4$ & 40 & 80 & 0.4 & 1000 \\
\hline
\end{tabular}

Table 7. Scratch parameters
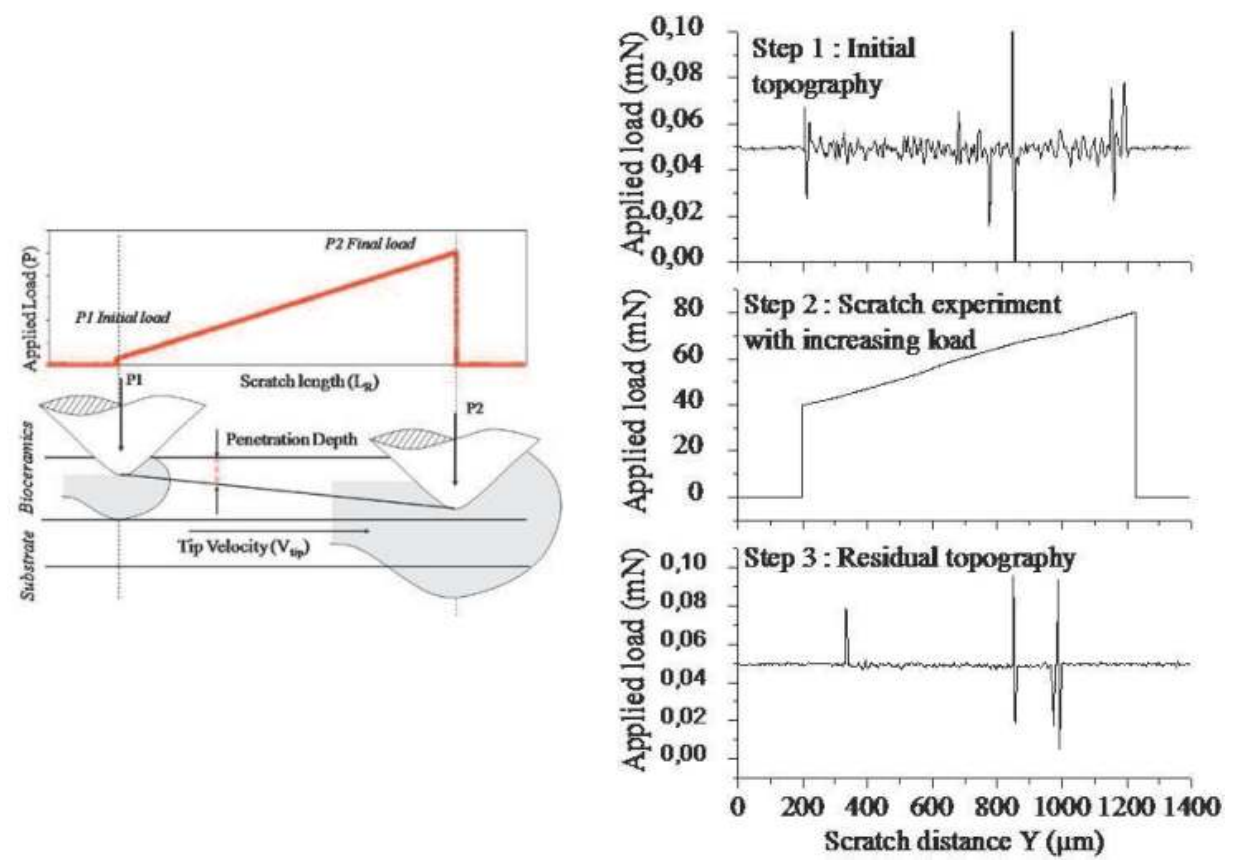

Fig. 13. Schematic description of a typical scratch procedure: step 1, original surface morphology, step 2, penetration depth during scratch, step 3, residual depth of the scratch groove.

Scratch experiments are known to be a more qualitative method compared to nanoindenation, and it is especially applied to compare the tribological response to friction of the tested surface during the same experimental procedure. In particular, scratch testing is widely used to determine the critical parameters for failure, such as the critical load which can be clearly seen when discontinuities appear on the different curves $h_{T}$ versus $F_{N}$ or $F_{T}$ versus $\mathrm{F}_{\mathrm{N}}$. A further parameter of importance for tribological behaviour of films is the friction coefficient, defined as the ratio $\mathrm{F}_{\mathrm{T}} / \mathrm{F}_{\mathrm{N}}$. 
In our study, residual scratch tracks were observed by SEM and compared to the experimental load-displacement curves during scratch to get access to the tribological properties of the deposited bioceramics in function of the used processes of elaboration (MS or PLD).

As observed for MS and PLD 5 samples, the failure and then detachment of the $\mathrm{Al}_{2} \mathrm{O}_{3}$ coating result in a abrupt changes in load-displacement curves, shown in Fig. 14(a-b), that show that critical load were reached. This is characteristic of an important release of an elastic energy during the propagation of cracks into $\mathrm{Al}_{2} \mathrm{O}_{3}$ films and then in the interface between the film and the underlying substrate, yielding to delamination. By contrast for the PLD 6 sample (Fig. 14c), no change in the $h_{T}$ versus $F_{N}$ curves is observed, proving that no ductile-brittle transition occurs for the tested normal load range. Same trend was observed for the PLD 4 sample but not presented here.
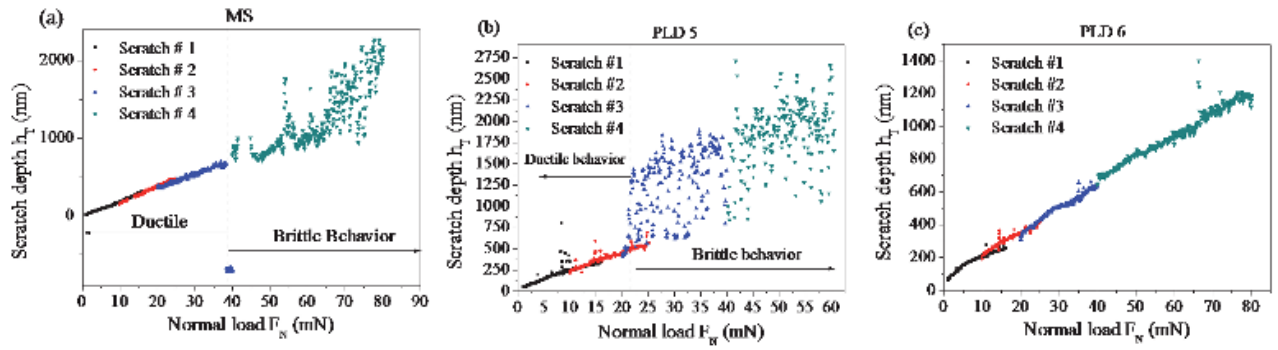

Fig. 14. Penetration depth as a function of the applied load during scratch measurements numbered 1 to 4 for (a) MS and (b-c) PLD 5 and PLD 6 samples.

SEM observations (Fig. 15), showing the scratch morphologies, clearly indicate that the initiation of failure occurs at the beginning of the scratch experiments for sample PLD 5 where partial cone track is initiated at the trailing edge of the spherical indenter, rapidly followed by delamination process of the $\mathrm{Al}_{2} \mathrm{O}_{3}$.
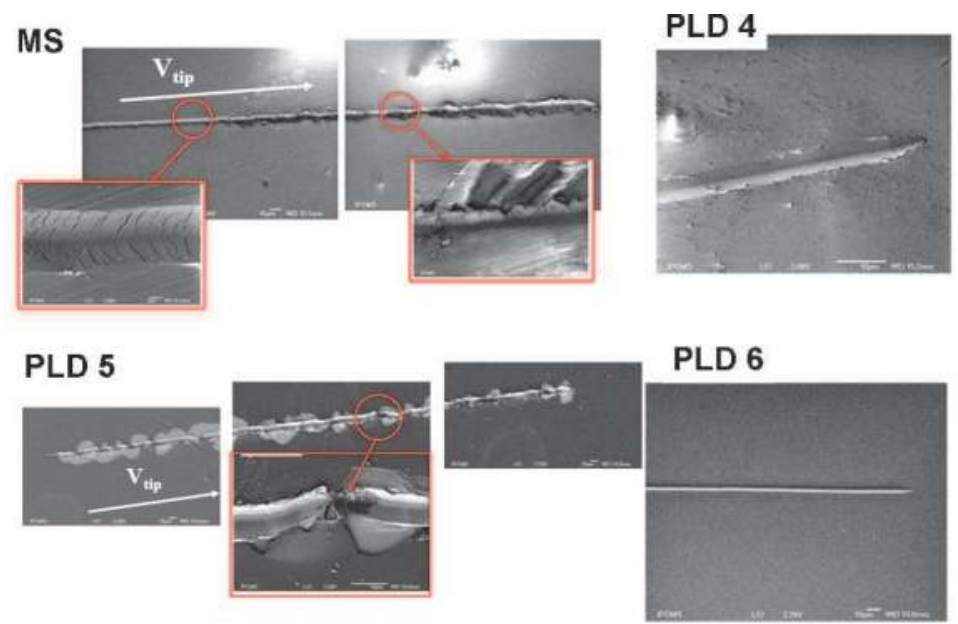

Fig. 15. SEM micrographs of the residual groove of scratch experiments 4 for the MS and PLD $\mathrm{Al}_{2} \mathrm{O}_{3}$ coatings 
For MS sample, failure events can be seen with cracks perpendicular to the scratch direction that appear on the bottom of the groove. These cracks are essentially due to the tensile stress at the trailing edge of the contact during friction. Furthermore, others cracks are visible on both sides of the scratch (Fig. 15). In contrast, PLD 4 and PLD 6 samples show no evidence of failure and a rather ductile behavior as seems to indicate the allure of the loaddisplacement curves for these samples (Fig. 14).

As mentioned with nanohardness measurements, the mechanical properties of PLD 6 are higher. It is important to note that the harder film (PLD 6) appears to be tougher than the softer (PLD 5), as determined by nanoindentation experiments exposed in the above section. However, failure processes are dependent on the deposition routes through residual stresses generated at the interface between film and substrate and also on the adhesion energy which can explain that MS sample (which shows the higher hardness compared to any PLD samples) is subject to cracking under nanoscratch. We can, however, notice that in comparison to PLD 5, these failure events appear with some delay and for a higher load.

Using the same tribological experimental conditions scratch tests were performed on the HA samples. Some results are given in Fig. 16 with increasing load from 0.75 to $15 \mathrm{mN}$ (realized in three steps) at the sliding speed of $10 \mu \mathrm{m} \mathrm{s}^{-1}$ (length scratch was $500 \mu \mathrm{m}$ ).

The HA tribological behaviour is opposed to one of $\mathrm{Al}_{2} \mathrm{O}_{3}$ layer. It is due to the surface morphology of this last one which is a dense, homogeneous and with weak roughness. Opposite tribological performance of the PLD HA on Ti substrate is conditioned by its topography presenting a high roughness due to the presence of droplets of different diameters and nanoaggregates. This can de described by the high level of oscillations in the penetration curves. The HA-1 and HA-2 analysis of curves cannot clearly show a distinct mechanical behaviour within the tested range of load.
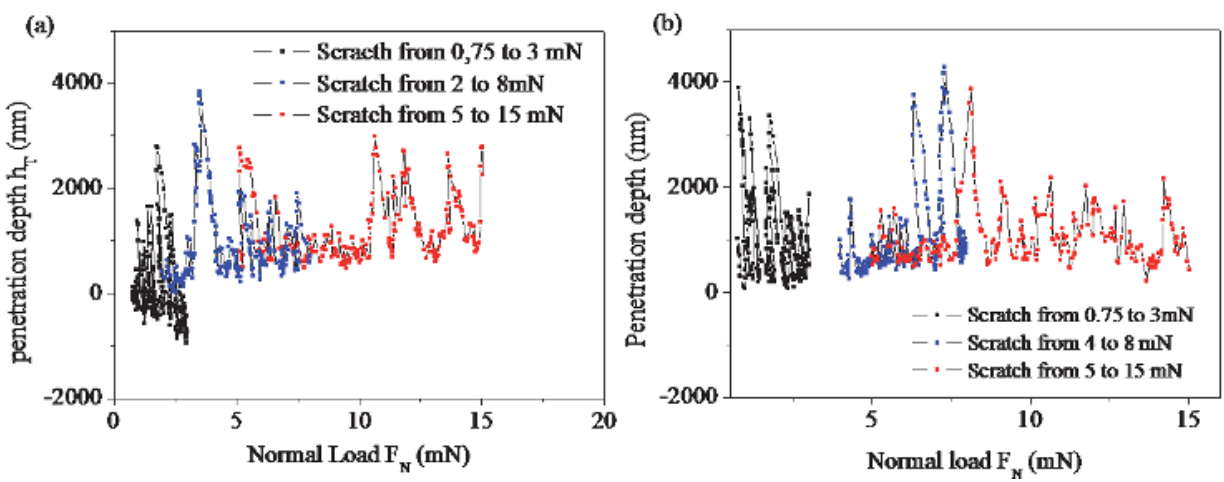

Fig. 16. Resistance to Penetration curves determined by scratch experiments on (a) HA-1 and (b) HA-2

\section{Conclusions}

Morphological, structural, nanoscratch and nanoindentation studies were performed to evaluate the composition, crystallinity status and mechanical properties of $\mathrm{Al}_{2} \mathrm{O}_{3} / 304 \mathrm{~L}$ and $\mathrm{HA} / \mathrm{Ti}$ structures synthesized by PLD and MS. We compared the characteristics of the substrates and their coatings deposited in different conditions. Alumina nanostructured 
films had a smooth surface, with few alumina particulates deposited on. They were stoichiometric, partially crystallized with an amorphous matrix. The obtained values of hardness and elastic modulus of the studied films are in good agreements with those found in literature. Different mechanical behaviours were observed in relation to different parameter of deposition (with or without working pressure in $\mathrm{O}_{2}$ ). By nanohardness and wear measurements, the mechanical properties of PLD 6 are higher. The harder PLD 6 film appears to be tougher than the softer films MS and PLD 5, as determined by nanoscratch experiments and validate by tribological tests. We also compared the characteristics of the HA synthesized with (HA-1) and without (HA-2) a post-deposition heat treatment in water vapour showing a well-crystallized, polycrystalline structure and an irregular HA morphology due to the chemical etching of the substrate and the presence of some HA particles and droplets, characteristic to PLD coatings.

Tribological behaviour of HA samples is mainly conditioned by the surface morphology as detected by the numerous oscillations on the scratch penetration curves. During scratching, the plastic strain is the leading deformation mechanism without failure event, at least in the tested load range.

These studies reveal that the pulsed-laser deposition and magnetron sputtering techniques appears extremely versatile technology and good candidates in tribological applications.

\section{Acknowledgements}

The authors wish to thank Prof I.N. Mihailescu and Dr. Sorin Grigorescu for performing PLD HA INFLPR of Bucharest in Romania; Mr. Jacques Faerber (IPCMS) for SEM characterizations; Mr. Guy Schmerber for preparing the MS alumina samples (IPCMS) and Mr. Gilles Versini (IPCMS) for the elaboration of PLD alumina samples. We acknowledge the financial support of Egide-Centre français pour l'accueil et les échanges internationaux by the PAI Brancusi (08867SD) and PAI IMHOTEP (12444SH) projects.

\section{References}

Ahn H. and Kwon D. (2000), Micromechanical estimation of composite hardness using nanoindentation technique for thin film coated system Materials Science and Enigineering A vol 285 p. 172 - 179, ISSN 09215093.

Arias J.L., Mayor M.B., Garcia-Sanz F.J., Pou J., Leon B., Perez-Amor M. \& Knowles J.C. (1997). Structural analysis of calcium phosphate coatings produced by pulsed laser deposition at different water-vapour pressures. Journal of Materials Science: Materials in Medicine, Vol. 8, No 12, pp. 873-876, ISSN 0957-4530.

Arias J.L., Mayor M.B., Pou J., León B. \& Pérez-Amor M. (2002). Transport of ablated material through a water vapor atmosphere in pulsed laser deposition of hydroxylapatite. Applied Surface Science, Vol. 186, No 1-4, 28 January 2002, pp. 448452, ISSN 0169-4332.

Babaluo A. A., Kokabi M., Manteghian M., Sarraf-Mamoory R. (2004). A modified model for alumina membranes formed by gel-casting followed by dip-coating. Journal of the European Ceramic Society, Vol. 24, No 15-16, pp. 3779-3787, ISSN 0955-2219.

Bordji G., Jouzeau J-Y., Mainard D., Payan E., Delagoutte J-P. \& Netter P. (1996). Evaluation of the effect of three surface treatments on the biocompatibility of 316L stainless 
steel using human differentiated cells. Biomaterials, Vol. 17, No 9, pp. 491-500, ISSN 0142-9612.

Buckle H., Applications to other material properties, in: J.W. Westbrook, H. Conrad (Eds.) The science of hardness testing and its research Applications, ASM, Metals Park, OH, 1973 p. $453-491$.

Cao W. \& Hench L. L., (1996). Bioactive ceramics. Ceramics International Vol. 22, pp. 493-507, ISSN 0272-8842.

Carradò A., Pelletier H., Fabre A., Barrallier L. \& Mihailescu I.N. (2008). A perspective of pulsed laser deposition in surface engineering: alumina coatings and substrates. Key Engineering Materials, Vol. 384, pp. 185-212, ISBN0-87849-372-7.

Carradò A., Schmerber G. \& Pelletier H. (2010), Structural and mechanical investigations of magnetron sputtering $\mathrm{TiO} 2 / \mathrm{Ti} / \mathrm{TiN}$ multilayer films on $\mathrm{Si}(100)$ substrate. Journal of Coatings Technology and Research, Vol. 7, No 6, pp. 821-829, ISSN 1547-0091.

Carradò A. \& Viart N., (2010). Nanocrystalline spin coated sol-gel hydroxyapatite thin films on Ti substrate: towards potential applications for implants. Solid State Science, Vol. 12, No. 7, pp. 1047-1050, ISSN 1293-2558.

Carradò A., (2010). Structural, Microstructural, and Residual Stress Investigations of Plasma-Sprayed Hydroxyapatite on Ti-6Al-4V. ACS Applied Materials \& Interfaces, Vol. 2, No. 2, pp. 561-565, ISSN 1944-8252.

Carradò A., Taha M. A. \& El Mahallawy N. A., (2010), Nanocrystalline $\gamma-\mathrm{Al}_{2} \mathrm{O}_{3}$ thin film deposited by magnetron sputtering (MS) at low temperature. Journal of Coatings Technology and Research, Vol. 7, No 4, pp. 515-519, ISSN 1547-0091.

Chen J., Tong W., Cao Y., Feng J. \& Zhang X. (1997). Effect of atmosphere on phase transformation in plasma-sprayed hydroxyapatite coatings during heat treatment. Journal of Biomedical Materials Research, Vol. 34, No. 1, pp. 15-20. ISSN 1549-3296

Chiba A., Kimura S., Raghukandan K. \& Morizono Y., (2003). Effect of alumina addition on hydroxyapatite biocomposites fabricated by underwater-shock compaction. Materials Science and Engineering A, Vol. 350, No 1-2, pp. 179-183. ISSN 0921-5093.

Cotell C.M., Pulsed laser deposition of biocompatible thin films, in: D.B. Chrisey, G.K. Hubler (Eds.), Pulsed Laser Deposition of Thin Films, Wiley, New York, (1994).

Dasarathy H., Riley C., Coble H.D., Lacefield W.R. \& Maybee G. (1996). Hydroxyapatite/metal composite coatings formed by electrocodeposition. Journal of Biomedical Materials Research, Vol. 31, No. 1, pp. 81-89. ISSN 1549-3296

de Groot K., Bioceramics of Calcium Phosphate. CRC Press, Boca Raton, FL, (1983).

Ducheyne P., Radin S. \& King L., (1993). The effect of calcium phosphate ceramic composition and structure on in vitro behavior. I. Dissolution. Journal of Biomedical Materials Research, Vol. 27, No.1, pp. 25-34. ISSN 1549-3296.

Elliot J.C., Structure and Chemistry of the Apatites and Others Orthophosphates, Elsevier, Amsterdam, (1994).

Filiaggi M.J., Pilliar R.M., Coombs N.A. (1993). Post-plasma-spraying heat treatment of the HA coating/Ti-6Al-4V implant system. Journal of Biomedical Materials Research, Vol. 27, No. 2, pp. 191-198, ISSN 1549-3296. 
Feng C.F., Khor K.A., Liu E.J. \& Cheang P., (1999). Phase transformations in plasma sprayed hydroxyapatite coatings. Scripta Materialia, Vol. 42, No; 1, pp. 103-109, ISSN 13596462.

Fernandez-Pradas J.M., Sardin G., Cleries L., Serra P., Ferrater C. \& Morenza J.L.. (1998). Deposition of hydroxyapatite thin films by excimer laser ablation. Thin Solid Films Vol. 317, No 1-2, pp. 393-396, ISSN 0040-6090.

Fernández-Pradas J.M., García- Cuenca M.V., Clèries L., Sardin G. \& Morenza J.L. (2002). Influence of the interface layer on the adhesion of pulsed laser deposited hydroxyapatite coatings on titanium alloy. Applied Surface Science, Vol. 195, No. 14, pp. 31-37, ISSN 0169-4332.

Hatton A., Nevelos J. E., Nevelos A. A., Banks R. E., Fisher J. \& Ingham E. (2002). Aluminaalumina artificial hip joints. Part I: a histological analysis and characterisation of wear debris by laser capture microdissection of tissues retrieved at revision. Biomaterials, Vol. 23, No 16, pp. 3429-3440, ISSN 0142-9612.

Hench L. L. (1991). Bioceramics: from concept to clinic. Journal of the American Ceramic Society, Vol. 74 pp. 1487-1510, ISSN 0002-7820.

Hench L.L. \& Wilson J., (1993). Introduction. In: L.L. Hench, J. Wilson, Editors, An introduction to bioceramics, Advanced series in ceramics vol. 1, World Scientific, Singapore 1993; pp. 1-24.

Hench L. L. (1998). Bioceramics. Journal of the American Ceramic Society, Vol. 81, No. 7, pp. 1705-1728, ISSN 0002-7820.

Holmberg K. \& Matthews A. Coatings-tribology. Amsterdam: Elsevier; 1994.

Husmann A., Gottmann J., Klotzbücher T. \& Kreutz E.W. (1998). Pulsed laser deposition of ceramic thin films using different laser sources. Surface and Coatings Technology, Vol. 100-101, pp. 411-414, ISSN 0257-8972.

Iliescu M., Nelea V., Werckmann J. \& Mihailescu I. N. (2004). Transmission electron microscopy investigation of pulsed-laser deposited hydroxylapatite thin films prepared by tripod and focused ion beam techniques. Surface and Coatings Technology, Vol. 187, No 1, pp. 131-140, ISSN 0257-8972.

Jelínek M., Olsan V., Jastrabík L., Studnicka V., Hnatowicz V., Kvítek J., Havránek V., Dostálova T., Zergioti I., Petrakis A., Hontzopoulos E. \& Fotakis C., (1995). Effect of processing parameters on the properties of hydroxylapatite films grown by pulsed laser deposition. Thin Solid Films, Vol. 257, No 1, 15 February 1995, pp. 125-129, ISSN 0040-6090.

Kao C.-T., Ding S.-J., Chen Y.-C. \& Huang T.-H. (2002). The anticorrosion ability of titanium nitride (TiN) plating on an orthodontic metal bracket and its biocompatibility. Journal of Biomedical Materials Research, Vol. 63, No. 6, pp. 786-792. ISSN 1549-3296.

Kasemo, B. (1983); Biocompatibility of titanium implants surface science aspects. Journal of Prosthetic Dentistry. Vol. 49, pp. 832-837. ISSN 0022-3913.

Knapp J.A., Follstaedt D.M., Myers S.M. (1996), precipitate hardened aluminium alloys formed using pulse laser deposition, Journal of Applied Phyics Vol. 79, Issue 2 p. 1116- 1122. ISSN 00218979. 
Koch B., Wolke J.G.C. \& de Groot K., (1990). X-ray diffraction studies on plasma-sprayed calcium phosphate-coated implants. Journal of Biomedical Materials Research Vol. 24, pp. 655-667. ISSN 1549-3296.

Kohn D.H., Ducheyne P. Materials for bone and joint replacement. In: Williams DF, editor. Medical and dental materials. Materials science and technology (a comprehensive treatment), Vol. 14. RW Cahn, P Haasen, EJ Kramer, collection editors. Weinheim:

Korsunsky A.M., McGurk M.R., Bull S.J., Page T.F., on the hardness of coated systems, Surface and Coatings Technology, 99 (1998) pp.171-183. ISSN 02578972.

Krebs H.-U., Störmer M., Faupel J., Süske E., Scharf T., Fuhse C., Seibt N., Kijewski H., Nelke D., Panchenko E. \& Buback M. (2003). Pulsed laser deposition (PLD) - a versatile thin film technique. Advances in Solid State Physics, Vol. 43, pp. 505-517. ISSN 14384329 .

Lacefield W.R. (1998). Current status of ceramic coatings for dental implants. Implant Dentistry Vol. 7, No 4, pp. 315-322, ISSN 1056-6163.

Legeros R.Z. \& Legeros J.P., (1993). Dense hydroxyapatite. In: L.L. Hench \& J. Wilson, Editors, An introduction to bioceramics. Advanced series in ceramics Vol. 1, pp. 139 World Scientific, Singapore.

Leng Y. X., Yang P., Chen J. Y., Sun H., Wang J., Wang G. J., Huang N., Tian X. B. \& Chu P. K. (2001). Fabrication of Ti-O/Ti-N duplex coatings on biomedical titanium alloys by metal plasma immersion ion implantation and reactive plasma nitriding/oxidation. Surface and Coatings Technology, Vol. 138, No 2-3, pp. 296-300, ISSN 0257-8972.

Li T.T., Lee J.H., Kobaysi T. \& Aoki H. (1996). Hydroxyapatite coating by dipping method, and bone bonding strength. Journal of Materials Science: Materials in Medicine, Vol. 7, No 6, pp. 355-357, ISSN 0957-4530.

Liu Y., Fischer T.E. \& Dent A., (2003). Comparison of HVOF and plasma-sprayed alumina/titania coatings-microstructure, mechanical properties and abrasion behaviour. Surface and Coatings Technology, Vol. 167, No 1, pp. 68-76, ISSN 02578972.

Long M. \& Rack H.J. (1998). Titanium alloys in total joint replacement-a materials science perspective. Biomaterials Vol. 19, No. 18, p. 1621- 1639, ISSN 0142-9612.

Mayor B., Arias J., Chiussi S., García F., Pou J., León B. \& Pérez-Amor M. (1998). Calcium phosphate coatings grown at different substrate temperatures by pulsed ArF-laser deposition. Thin Solid Films, Vol. 317, No 1-2, pp. 363-366, ISSN 0040-6090.

Nelea V., Pelletier H., Muller D., Broll N., Mille P., Ristoscu C. \& Mihailescu I.N. (2002). Mechanical properties improvement of pulsed laser-deposited hydroxyapatite thin films by high energy ion-beam implantation. Applied Surface Science, Vol. 186, No. 14, pp. 483-489, ISSN 0169-4332.

Nelea V., Jelinek M. \& Mihailescu I. N., (2006). Biomaterials: new issues and breakthroughs for biomedical applications in: R. Eason (Ed.) Pulsed Laser Deposition of thin films: applications-lead growth of functional materials", Wiley \& Sons, New York.

Nieh T.G, Jankowski A.F, Koike J. (2001), Processing and characterization of hydroxyapatite coatings on titanium produced by magnetron sputtering, Journal of Materials Research Vol 16, pp 3238 -3245, ISSN 08842914. 
Oshida Y., Tuna E.B., Aktören O. \& Gençay K. (2010). Dental Implant Systems. International Journal of Molecular Science, Vol. 11, No 4, pp. 1580-1678, ISSN 1422-0067.

Oliver W.C., Pharr G.M. (1992), Measurement of hardness and elastic modulus by instrumented indentation, Journal of Materials Research Vol. 7, issue 4, pp1564-1583.

Pelletier H., Carradò A., Faerber J. \& Mihailescu I. N., (2011). Microstructure and mechanical characteristics of hydroxyapatite coatings on Ti/TiN/Si substrates synthesized by pulsed laser deposition. Applied Physics A: Materials Science \& Processing, 2011, Vol. 102, No. 3, pp. 629-640, ISSN 1432-0630.

Radin S.R. \& Ducheine P. (1992). Plasma spraying induced changes of calcium phosphate ceramic characteristics and the effect in vitro stability. Journal of Materials Science: Materials in Medicine, Vol. 3, No 1, pp. 33-42, ISSN 0957-4530.

Ruhi G., Modi O.P., Sinha A.S.K.\& Singh I.B. (2008). Effect of sintering temperatures on corrosion and wear properties of sol-gel alumina coatings on surface pre-treated mild steel. Corrosion Science, Vol. 50, No 3, pp. 639-649. ISSN 0010-938X.

Saha R. and Nix W.D. (2002), Effect of the substrate on the determination of thin film mechanical properties by nanoindentation, Acta Materialia, Vol 50, No 11, pp. 23 38, ISSN 1359-6454.

Staia M.H., Levis B., Cawley J. \& Hendson T., (1995). Chemical vapour deposition of TiN on stainless steel. Surface and Coatings Technology, Vol. 76-77, No 1, pp. 231-236, ISSN 0257-8972.

Sun Y., Bell T., Zheng S. (1995) Finite element analysis of the critical ratio of coating thickness to indentation depth for coating property measurements by nanoindentation, Thin Solid Films, Vol. 258, No 1, pp. 198-204, ISSN 00406090

Tamura, Y., Yokoyama, A., Watari, F. \& Kawasaki, T. (2002). Surface properties and biocompatibility of nitrided titanium for abrasion resistant implant materials. Dental Material Journal, Vol. 21, pp. 355-372. ISSN 02874547.

Tisdel C. L., Golberg V. M, Parr J. A., Bensuan J. S., Staikoff L. S. \& Stevenson S. (1994). The influence of a hydroxyapatite and tricalcium-phosphate coating on bone growth into titanium fiber-metal implants. Journal of Bone E Joint Surgery (US Volume),Vol. 76, No 2, pp. 159-171. ISSN 00219355.

Trinh D.H., Kubart T., Nyberg T., Ottosson M., Hultman L. \& Högberg H. (2008). Direct current magnetron sputtering deposition of nanocomposite alumina - zirconia thin films. Thin Solid Films, Vol. 516, No 23, pp. 8352-8358, ISSN 0040-6090.

Wasa K., Kitabatake M., Adachi H., Thin Film Materials Technology: Sputtering of Compound Materials, Noyes Publications, 2003.

Weng J., Liu X.G., Li X.D. \& Zhang X.D., (1995). Intrinsic factors of apatite influencing its amorphization during plasma-spray coating. Biomaterials, Vol. 16, No. 1, 1995, pp. 39-44, ISSN 0142-9612

Yang C.Y., Wang B.C., Chang E. \& Wu J.D. (1995). The influences of plasma spraying parameters on the characteristics of hydroxyapatite coatings: a quantitative study. Journal of Materials Science: Materials in Medicine, Vol. 6, pp. 249-257, ISSN 09574530 . 
Yang Y., Kim K-H \& Ong J. L. (2005). A review on calcium phosphate coatings produced using a sputtering process - an alternative to plasma spraying. Biomaterials, Vol. 26, No. 3, pp. 327-337, ISSN 0142-9612.

Zhang C., Leng Y., Chen J. (2001), amorphous and recristallisation during plasma spraying of hydroxyapatite, Biomaterials, Vol. 22, No 11, pp. 1357 -1363.

Zeng H. \& Lacefield W.R. (2000). XPS, EDX and FTIR analysis of pulsed laser deposited calcium phosphate bioceramic coatings: the effects of various process parameters. Biomaterials, Vol. 21, No 1, pp. 23-30, ISSN 0142-9612. 


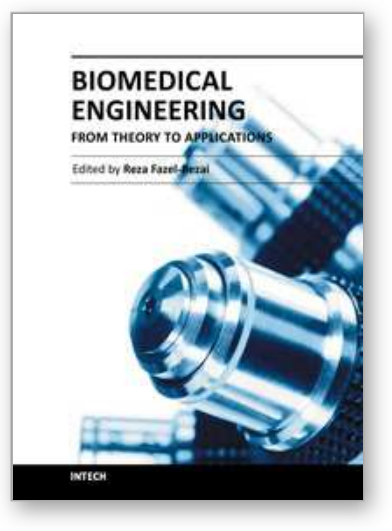

\author{
Biomedical Engineering - From Theory to Applications \\ Edited by Prof. Reza Fazel
}

ISBN 978-953-307-637-9

Hard cover, 486 pages

Publisher InTech

Published online 29, August, 2011

Published in print edition August, 2011

In all different areas in biomedical engineering, the ultimate objectives in research and education are to improve the quality life, reduce the impact of disease on the everyday life of individuals, and provide an appropriate infrastructure to promote and enhance the interaction of biomedical engineering researchers. This book is prepared in two volumes to introduce a recent advances in different areas of biomedical engineering such as biomaterials, cellular engineering, biomedical devices, nanotechnology, and biomechanics. It is hoped that both of the volumes will bring more awareness about the biomedical engineering field and help in completing or establishing new research areas in biomedical engineering.

\title{
How to reference
}

In order to correctly reference this scholarly work, feel free to copy and paste the following:

Adele Carradò, Hervé Pelletier and Thierry Roland (2011). Nanocrystalline Thin Ceramic Films Synthesised by Pulsed Laser Deposition and Magnetron Sputtering on Metal Substrates for Medical Applications, Biomedical Engineering - From Theory to Applications, Prof. Reza Fazel (Ed.), ISBN: 978-953-307-637-9, InTech, Available from: http://www.intechopen.com/books/biomedical-engineering-from-theory-toapplications/nanocrystalline-thin-ceramic-films-synthesised-by-pulsed-laser-deposition-and-magnetronsputtering-o

\section{INTECH}

open science | open minds

\author{
InTech Europe \\ University Campus STeP Ri \\ Slavka Krautzeka 83/A \\ 51000 Rijeka, Croatia \\ Phone: +385 (51) 770447 \\ Fax: +385 (51) 686166 \\ www.intechopen.com
}

\author{
InTech China \\ Unit 405, Office Block, Hotel Equatorial Shanghai \\ No.65, Yan An Road (West), Shanghai, 200040, China \\ 中国上海市延安西路65号上海国际贵都大饭店办公楼 405 单元 \\ Phone: +86-21-62489820 \\ Fax: +86-21-62489821
}


(C) 2011 The Author(s). Licensee IntechOpen. This chapter is distributed under the terms of the Creative Commons Attribution-NonCommercialShareAlike-3.0 License, which permits use, distribution and reproduction for non-commercial purposes, provided the original is properly cited and derivative works building on this content are distributed under the same license. 